\title{
Metallothionein is elevated in liver and duodenum of $\operatorname{Atp} \mathbf{b}^{(-/-)}$mice
}

\author{
Chengcheng Christine Zhang $\mathbb{B} \cdot$ Martin Volkmann - Sabine Tuma \\ Wolfgang Stremmel • Uta Merle
}

Received: 22 March 2018/ Accepted: 1 May 2018/Published online: 7 May 2018

(C) The Author(s) 2018

\begin{abstract}
Different mutations in the copper transporter gene Atp7b are identified as the primary cause of Wilson's disease. These changes result in high copper concentrations especially in the liver and brain, and consequently lead to a dysfunction of these organs. The $\operatorname{Atp} 7^{(-1-)}$ mouse is an established animal model for Wilson's disease and characterized by an abnormal copper accumulation, a low serum oxidase activity and an increased copper excretion in urine. Metallothionein (MT) proteins are low molecular weight metal-binding proteins and essential for the zinc homeostasis but also play a role for the regulation of other metals, e.g. copper. However the molecular mechanisms of MT in regard to Atp7b remain still elusive. In this study we investigate the expression of MT in the liver and duodenum of Atp $7 \mathrm{~b}^{(-/-)}$mice and wildtype mice. Hepatic and duodenal expression of MT was measured by real-time reverse transcriptionpolymerase chain reaction and post-translational expression was analyzed by immunoblot and immunofluorescence. Expression of MT in liver und duodenum was significantly higher in Atp $7 \mathrm{~b}^{(-/-)}$mice
\end{abstract}

C. C. Zhang $(\bowtie) \cdot$ S. Tuma $\cdot$ W. Stremmel $\cdot$ U. Merle Department of Gastroenterology, University Hospital Heidelberg, Heidelberg, Germany e-mail: chengchengchristine.zhang@med.uniheidelberg.de

M. Volkmann

Labor Prof Dr H.-P. Seelig \& Kollegen, Karlsruhe, Germany than in controls. Hepatic and duodenal copper, iron and zinc content were also studied. Compared to control hepatic copper and iron content was significantly higher while hepatic zinc content was significantly lower in Atp $7 \mathrm{~b}^{(-/-)}$mice. In the duodenum copper and zinc content of Atp $7 b^{(-/-)}$mice was significantly lower than in controls. Duodenal iron content was also lower in Atp7 $\mathrm{b}^{(-/-)}$mice, but did not reach statistical significance. The results of our study suggest that metallothionein is elevated in the liver and duodenum of Atp $7 \mathrm{~b}^{(-/-)}$mice.

Keywords Wilson's disease - Atp7b .

Metallothionein $\cdot$ Copper $\cdot$ Liver $\cdot$ Duodenum

$\begin{array}{ll}\text { Abbreviations } \\ \text { MT } & \text { Metallothionein } \\ \mathrm{Cu} & \text { Copper } \\ \mathrm{Fe} & \text { Iron } \\ \mathrm{Zn} & \text { Zinc } \\ \mathrm{Cd} & \text { Cadmium }\end{array}$

\section{Introduction}

Wilson's disease is an autosomal recessively inherited disorder of copper metabolism, caused by mutations in the Atp7b gene on chromosome 13 (Bull et al. 1993; Tanzi et al. 1993). The corresponding protein Atp7b is 
a Cu-ATPase. Being primarily expressed in the hepatocytes Atp7b serves as a mediator for the incorporation of $\mathrm{Cu}$ into ceruloplasmin and the excretion of $\mathrm{Cu}$ from the liver into the bile (Lutsenko et al. 2007). Therefore Wilson's disease is characterized by an excessive copper accumulation in a number of tissues, especially in liver and brain, which also leads to the phenotypical characteristics of the disorder: neurological symptoms and hepatitis and/or cirrhosis (Ferenci et al. 2003).

Established animal models for Wilson's disease are the Long Evans Cinnamon (LEC) rat (Wu et al. 1994), the toxic milk mouse (Theophilos et al. 1996) and the Atp7b $\mathrm{b}^{(-/-)}$mouse (Buiakova et al. 1999; Huster et al. 2006). All these animal models are characterized by hepatic copper accumulation and liver damage (Buiakova et al. 1999; Okayasu et al. 1992). In patients with Wilson's disease liver copper concentrations become elevated during the evolution of the disorder. The accumulated copper is thought to be detoxified by metallothionein (MT) (Suzuki 1995). MTs are low molecular weight ( 6-7 kDa) proteins that are present in most cell types and bind unusually high amounts of heavy metal ions such as $\mathrm{Cu}, \mathrm{Zn}$ and Cd (7-20 atoms/molecule). MT is mainly a cytoplasmatic protein but it is also present in the nucleus during development, cell proliferation and regeneration (Nishimura et al. 1989; Tohyama et al. 1993). MT is thought to be involved in the homeostasis of essential metals, copper and zinc, as it is the major zinc and copper binding protein in many tissues, and there is a close relationship between tissue MT and zinc content (Bremner 1991). In humans 11 isoforms of MTs are described. The most widely expressed MT isoforms in mammals, MT-1 and MT-2, are rapidly induced in the liver by a wide range of metals, drugs and inflammatory mediators. Although MT is thought to play a crucial role in the metabolism, transport, homeostasis and toxicity or detoxification of certain metals, an unequivocally established function is still lacking (Coyle et al. 2002). Previously it has been shown that liver MT concentrations are increased $\sim$ threefold in patients with Wilson's disease compared to controls (Mulder et al. 1992; Nartey et al. 1987). Established therapeutic options for patients with Wilson's disease are D-penicillamine (DPA), trientine and zinc salts. Induction of duodenal MT expression is commonly accepted to play an important role in zinc therapy for Wilson's disease. It is hypothesized that intestinal MT induction mediates the decreased copper absorption observed during zinc therapy for Wilson's disease. However the molecular mechanisms of MTs in regard to the copper transporter Atp $7 b$ are still unclear.

Therefore the aims of our study were to analyze hepatic and duodenal MT expression of Atp $7 \mathrm{~b}^{(-/-)}$ mice compared to wildtype mice.

\section{Materials and methods}

Animals

The generation of Atp $7 b^{(-/-)}$mice has been described previously (Buiakova et al. 1999). The Atp7b ${ }^{(-/-)}$ mice (with a genetic 129S1/Sv background) and the wildtype $129 \mathrm{~S} 1 / \mathrm{Sv}$ mice were housed at the University of Heidelberg according to the guidelines of the Institutional Animal Care and Use Committees and in accordance with government guidelines. Male Atp $7 \mathrm{~b}^{(-/-)}$and wildtype mice with an age of 13 weeks were used for the experiments ( $\mathrm{n}=5$ per group). Mice were kept on a 12:12 light/dark cycle. Food (normal chow diet containing $176 \mu \mathrm{g} / \mathrm{g}$ iron and $16 \mu \mathrm{g} / \mathrm{g}$ copper) and water were provided ad libitum.

Animals were anesthetized with ketamine/xylazine and systematically perfused with saline from the left ventricle after thoracotomy to remove whole blood from organs. Subsequently livers and duodenum were removed and stored for further analysis.

Measurement of metal content

Iron, copper and zinc quantification in liver and duodenal tissues using atomic absorption spectroscopy was performed as described previously (Nicholson et al. 1989). Iron, copper and zinc concentrations of tissues (mg/g of wet tissue) were calculated from the results of this analysis (Widdowson et al. 1972; Widdowson and Spray 1951).

\section{Quantitative RT-PCR}

Total RNA was isolated from liver and duodenum samples using the RNAeasy Mini Kit (Qiagen, Hilden, Germany) including DNAse digestion according to manufacturer's instructions. As previously described (Herrmann et al. 2004; Muckenthaler et al. 2003), real- 
time quantification of mouse mRNA transcripts was performed with a two-step RT-PCR using the LightCycler system and the Relative Quantification Software Version 1.0 (Roche Diagnostics, Mannheim, Germany).

Sense and antisense primers for mouse MT-1 and MT-2 were: MT-1, 5'-ACT TGC ACC AGC TCC TGC- $3^{\prime}$ and $5^{\prime}$-CGT CAC ATC AGG CAC AGC-3'; and MT-2, 5'-TCT CGT CGA TCT TCA ACC G-3' and $5^{\prime}$-TGT CGG AAG CCT CTT TGC-3'. Calibrators were generated from EST clones from RZPD, Berlin, Germany as described previously (14-16, FePaper). Calibrators for mouse MT-1 and MT-2 were generated from EST clones IMAGE:476323, IMAGE:4037047, and IMAGE:2651471, respectively. Normalization to actin mRNA levels was performed as previously described (Gehrke et al. 2003; Herrmann et al. 2004).

\section{Western blotting}

MT protein in mouse liver and duodenum was analyzed by Western blotting. Frozen liver and duodenal tissues (100 mg wet weight) were minced and homogenized in 10 volumes of lysis buffer (10 mM HEPES-NaOH(pH 7.2), $0.25 \mathrm{M}$ sucrose, $5 \mathrm{mM}$ EDTA) containing $1 \mathrm{mM}$ phenylmethylsulfonylfluoride and proteinase inhibitors (Roche, Mannheim, Germany). The homogenates were centrifuged for $10 \mathrm{~min}$ at $600 \times g$ at $4{ }^{\circ} \mathrm{C}$. Total protein concentrations were determined on these homogenates using the Bio-Rad (Bradford) protein assay (Bio-Rad, Hercules, CA) with bovine serum albumin as a standard. Soluble protein (50 $\mu \mathrm{g}$ per lane) was separated on $15 \%$ polyacrylamide gels and blotted onto PVDF membrane (Bio-Rad, Munich, Germany) by standard procedures. Membranes were blocked in 5\% nonfat dried milk (Bio-Rad) in PBS/PBST (139 mM NaCl, $2.7 \mathrm{mM} \mathrm{KH} \mathrm{KH}_{2} \mathrm{PO}_{4}, 9.9 \mathrm{mM} \mathrm{Na} \mathrm{HPO}_{4}$, and $0.05 \%$ Tween 20) and were then incubated overnight with primary antibodies. As primary antibodies for detection of $M T$ the mouse monoclonal antibody UC1MT (diluted 1:1000; Abcam, Heidelberg, Germany) was used. Mouse monoclonal antibodies specific for $\alpha-$ actin (1:10,000, Sigma, Munich, Germany) served as loading control. After washing in PBST, immunoreactive proteins were visualized after incubation with horseradish oxidase-conjugated secondary antibodies goat anti-mouse antibody (diluted 1:7500; Santa Cruz
Biotechnology, Heidelberg, Germany) using ECL immunoblotting detection reagents (Amersham Pharmacia, Uppsala, Sweden). Molecular mass marker used was PageRuler (Fermentas, St. Leon-Roth, Germany).

Immunofluorescence analysis

Five micrometer thick serial cryostat sections were used. After blocking with $3 \%$ bovine serum albumin in PBS (pH 7.4) for $2 \mathrm{~h}$ at room temperature, sections were incubated with MT goat polyclonal N-19 (diluted 1:300; Santa Cruz Biotechnology, Heidelberg, Germany), overnight at $4{ }^{\circ} \mathrm{C}$, followed by incubation with Cy3-coupled secondary antibody (diluted 1:500; Dianova, Hamburg, Germany). Nuclei staining was done with Hoechst (diluted 1:10 for $10 \mathrm{~min}$; Sigma, Munich, Germany). Immunostaining was visualized on a Leica fluorescence microscope equipped with a high pressure mercury lamp and the appropriate filter sets. Images were acquired with a digital camera and processed with MetaVue software (Universal Imaging; Visitron, Puchheim, Germany).

Statistical analysis

Data were expressed as means \pm standard deviations. We used the unpaired Student's $t$ test to evaluate the differences in hepatic copper content and gene expression level on real-time RT-PCR between Atp $7 \mathrm{~b}^{(-1-)}$ and wild-type mice. A P value less than 0.05 was considered significant. Statistical analyses were performed with SPSS for Windows, release 10.05 (SPSS, Chicago, IL).

\section{Results}

Metallothionein is elevated in the liver and duodenum of Atp $7 \mathrm{~b}^{(-/-)}$mice

Metallothionein is a low molecular metal binding protein and essential in zinc homeostasis. MT is also known to bind copper and iron. MT-1 and MT-2 are the most widely expressed MT isoforms in mammals. To determine whether metallothionein is involved in our previous findings we measured the hepatic metallothionein expression on mRNA level by means of quantitative real-time RT-PCR in relation to the 
expression levels of the housekeeping gene actin and we could show that the hepatic MT-1 expression of Atp $7 \mathrm{~b}^{(-/-)}$mice was more than 400 -fold higher than in wildtype mice $(356.8 \pm 134.37 \mathrm{MT}-1 /$ actin ratio $\left(\times 10^{-1}\right.$ vs. $0.84 \pm 0.31 \mathrm{MT}-1 /$ actin ratio $\left(\times 10^{-1}\right)$; $\mathrm{P}<0.001 ; \mathrm{n}=5$ per group) (Fig. 1a). And MT-2 expression in liver of Atp $7 \mathrm{~b}^{(-1-)}$ mice was more than 900-fold higher than in wildtype mice $\left(137.86 \pm 62.19\right.$ MT-2/actin ratio $\left(\times 10^{-2}\right)$ vs. $0.14 \pm 0.05$ MT-2/actin ratio $\left.\left(\times 10^{-2}\right) ; \mathrm{P}<0.001\right)$ (Fig. 1b).

In the duodenum MT-1 was expressed on mRNA level fivefold higher in Atp7 $\mathrm{b}^{(-1-)}$ mice when compared to wildtype mice $(12.08 \pm 5.177$ MT-1/actin ratio $\left(\times 10^{-1}\right)$ vs. $2.36 \pm 1.81 \mathrm{MT}-1 /$ actin ratio $\left(\times 10^{-1}\right) ; \mathrm{P}=0.007$ ) (Fig. 1c). And MT-2 expression in duodenum of Atp7 $\mathrm{b}^{(-1-)}$ mice was 18-fold higher than in wildtype mice (4.44 \pm 2 MT-2/actin ratio $\left(\times 10^{-2}\right)$ vs. $0.24 \pm 0.16$ MT-2/actin ratio $\left(\times 10^{-2}\right)$; $\mathrm{P}=0.003$ ) (Fig. 1d).

In the next step we also investigated the MT expression on protein level by western blotting. MT expression in the liver was strongly detectable in Atp $7 b^{(-/-)}$mice by immunoblot analyzes. In wildtype mice there was significantly less MT expression detectable (Fig. 2a). In the duodenum MT expression was slightly stronger in $\operatorname{Atp} 7 \mathrm{~b}^{(-/-)}$mice than in wildtype (Fig. 2b).

MT is mainly a cytoplasmatic protein but it is also present in the nucleus during development, cell proliferation and regeneration (Nishimura et al. 1989; Tohyama et al. 1993). To detect the localization of metallothionein in duodenum and liver we performed an immunofluorescence microscopy. As shown in Fig. 3 there was a slightly stronger expression of MT (shown in red) detectable in the liver of Atp $7 b^{(-/-)}$mice in comparison to wildtype mice (Fig. 3a, b). The expression pattern of MT was detectable in the cytoplasma and nucleus of the liver in both groups. In the duodenum MT localizes more to the cytoplasma than to the nucleus in both, Atp $7 \mathrm{~b}^{(-/-)}$ mice and wildtype mice (Fig. 3c, d).

Hepatic copper and iron concentrations are elevated and hepatic zinc concentration is decreased in Atp $7 \mathrm{~b}^{(-/-)}$mice

Total copper measurements were done in liver samples from male 13 -week-old Atp $7 b^{(-/-)}$and wildtype mice. As shown in Fig. 4a, Atp7 $\mathrm{b}^{(-/-)}$mice showed a 52-fold higher hepatic copper content in liver than wildtype mice $(275.92 \pm 27.93$ vs. $5.32 \pm 0.36 \mu \mathrm{g} / \mathrm{g}$ of wet weight, $\mathrm{P}<0.001 ; \mathrm{n}=5$ per group).

We also measured the iron concentrations of the liver samples of both Atp $7 b^{(-/)}$and wildtype mice. The iron content of the liver was 2-fold higher in Atp $7 \mathrm{~b}^{(-1-)}$ mice compared to wildtype mice $(103 \pm 18.60$ vs. $60.6 \pm 14.39 \mu \mathrm{g} / \mathrm{g}$ of wet weight, $\mathrm{P}=0.007$ ) (Fig. 4b).

As the function of metallothionein is closely linked to zinc, we also looked for the zinc concentration. In the liver zinc content was also significantly lower in $A_{t p 7 b}{ }^{(-1-)} \quad$ mice $\quad(53.88 \pm 1.72 \quad$ vs. $93.44 \pm 14.68 \mu \mathrm{g} / \mathrm{g}$ of wet weight, $\mathrm{P}<0.001)$ than in controls (Fig. 4c).

Duodenal copper and zinc concentration are decreased in Atp $7 b^{(-/-)}$mice

In the next step we measured the copper and iron concentrations in the duodenum. As shown in Fig. 5a, Atp $7 b^{(-1-)}$ mice showed a copper content in the duodenum that was only half as high than in wildtype mice $(11.98 \pm 2.87$ vs. $22.96 \pm 6.83 \mu \mathrm{g} / \mathrm{g}$ of wet weight, $\mathrm{P}=0.018 ; \mathrm{n}=5$ per group).

There was no significant difference of the duodenal iron content in Atp $7 \mathrm{~b}^{(-1-)}$ mice compared with wildtype mice $\quad(235.14 \pm 70.11 \quad$ vs. $339.34 \pm 135.04 \mu \mathrm{g} / \mathrm{g}$ of wet weight, $\mathrm{P}=0.21$ ) (Fig. 5b).

As shown in Fig. 5c the zinc content in the duodenum of Atp $7 b^{(-1-)}$ mice was significantly lower and only half as high as the zinc content in the duodenum of wildtype mice $(136.04 \pm 19.52$ vs. $294.02 \pm 88.31 \mu \mathrm{g} / \mathrm{g}$ of wet weight, $\mathrm{P}=0.008$ ).

\section{Discussion}

Wilson's disease is characterized by an extreme accumulation of copper by mutations in the copper transporter gene Atp7b (Tanzi et al. 1993). This leads to cerebral and hepatic dysfunctions. Metallothioneins are low-molecular-weight metal-binding proteins and are thought to play an essential role in the zinc homeostasis, prevention of heavy metal-induced cytotoxicity and protection against environmental stress, but an unequivocally established function is still 

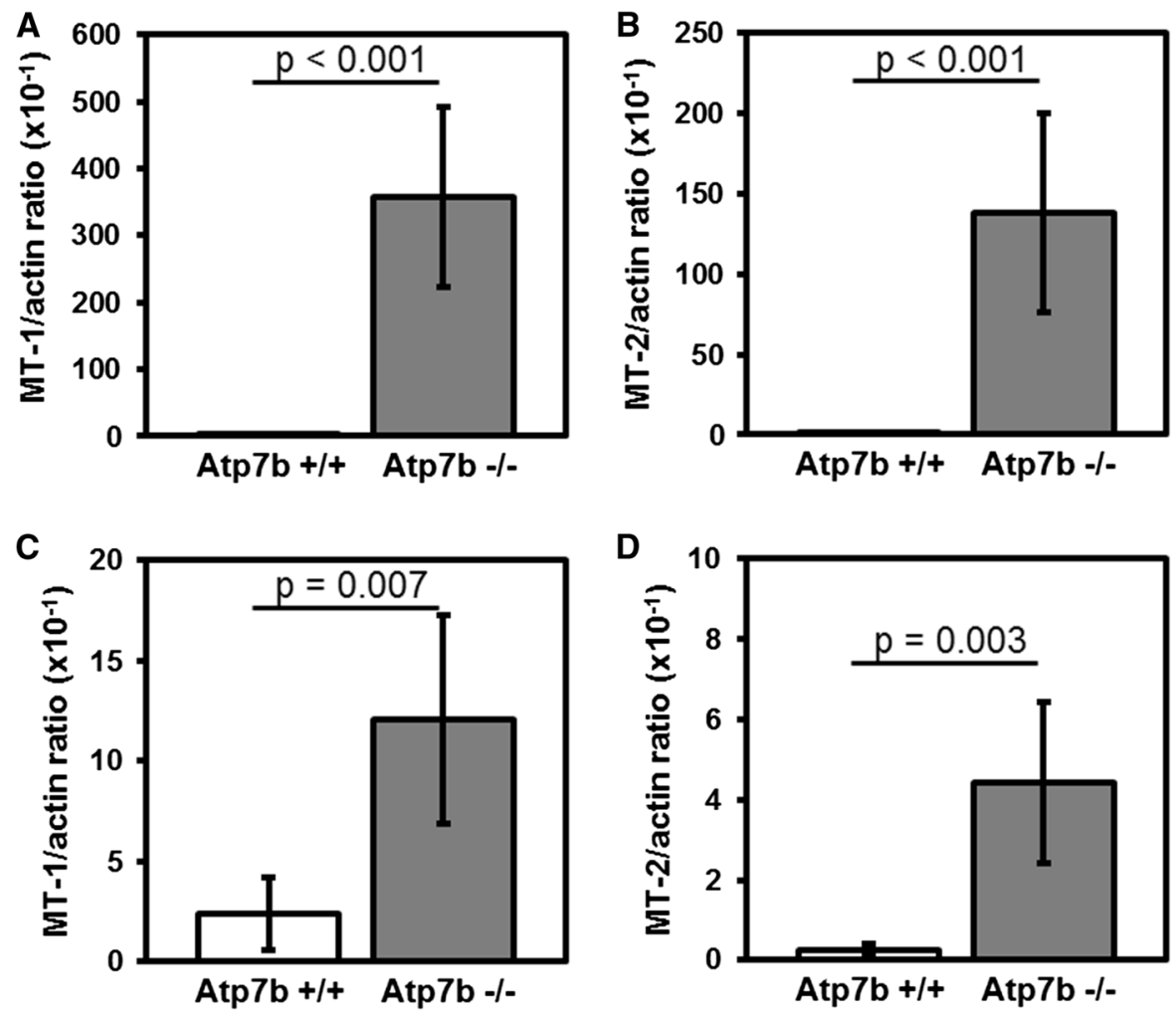

Fig. 1 Hepatic and duodenal expression of metallothionein 1 and 2 (MT) on mRNA level. Quantification was done by realtime reverse transcription-polymerase chain reaction (RT-PCR) and expressed in relation to actin. Data are expressed as means \pm standard error. a Hepatic MT1 expression of Atp $7 \mathrm{~b}^{(-/-)}$mice compared with wildtype mice $(\mathrm{n}=5$ per group). Hepatic MT1 expression is significantly higher in Atp7 $\mathrm{b}^{(-/-)}$mice compared with wildtype mice. b Hepatic MT2 expression of $A \operatorname{tp} 7 b^{(-1-)}$ mice compared with wildtype mice.

A

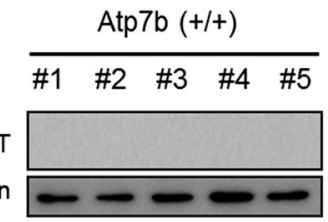

B

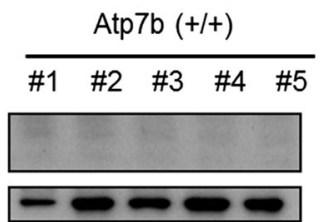

Fig. 2 Hepatic and duodenal expression of metallothionein 1 and 2 (MT) on protein level. a, b Western Blots of liver (a) and duodenum (b) homogenate $\left(50 \mu \mathrm{g}\right.$ protein) of Atp $7 \mathrm{~b}^{(-/-)}$mice and wildtype mice using mouse anti-MT (upper panel). Antiactin served as gel loading control (lower panel)

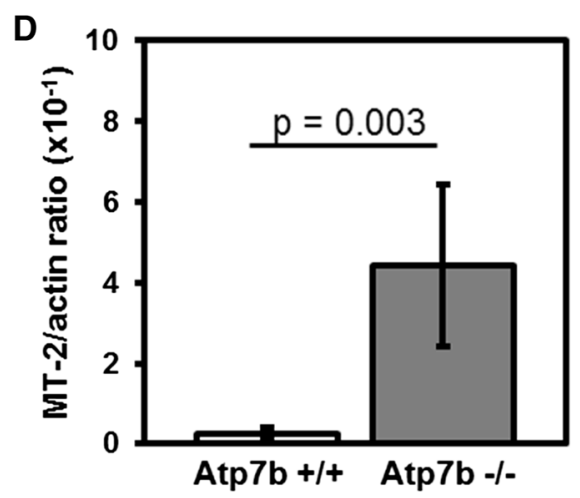

Hepatic MT2 expression is significantly higher in Atp7b ${ }^{(-/-)}$ mice compared with wildtype mice. c Duodenal MT1 expression of Atp $7 \mathrm{~b}^{(-1-)}$ mice compared with wildtype mice. Duodenal MT1 expression is significantly higher in Atp $7 \mathrm{~b}^{(-1-)}$ mice compared with wildtype mice. d Duodenal MT2 expression of $\operatorname{Atp} 7 \mathrm{~b}^{(-1-)}$ mice compared with wildtype mice. Duodenal MT2 expression is significantly higher in Atp7 $\mathrm{b}^{(-1-)}$ mice compared with wildtype mice

lacking (Coyle et al. 2002). Four major isoforms are described for mammalian MTs: MT-1, $-2,-3$ and -4 . MT-1 and MT-2 only slightly differ in regard to their amino acid sequences and are expressed in most of the organs (Hamer 1986). Previously it has been described that MT concentrations are increased $\sim$ threefold in patients with Wilson's disease compared to controls (Mulder et al. 1992; Nartey et al. 1987). Excessive accumulated copper in the liver binds to metallothionein and only reacts in a toxic way if the binding capacity of MT is exhausted and free copper occurs (Sakurai et al. 1992a; Sugawara et al. 1991). However the molecular mechanisms of MTs in regard to the copper transporter Atp7b are still unclear and to unravel the mechanisms, we investigated the MT 

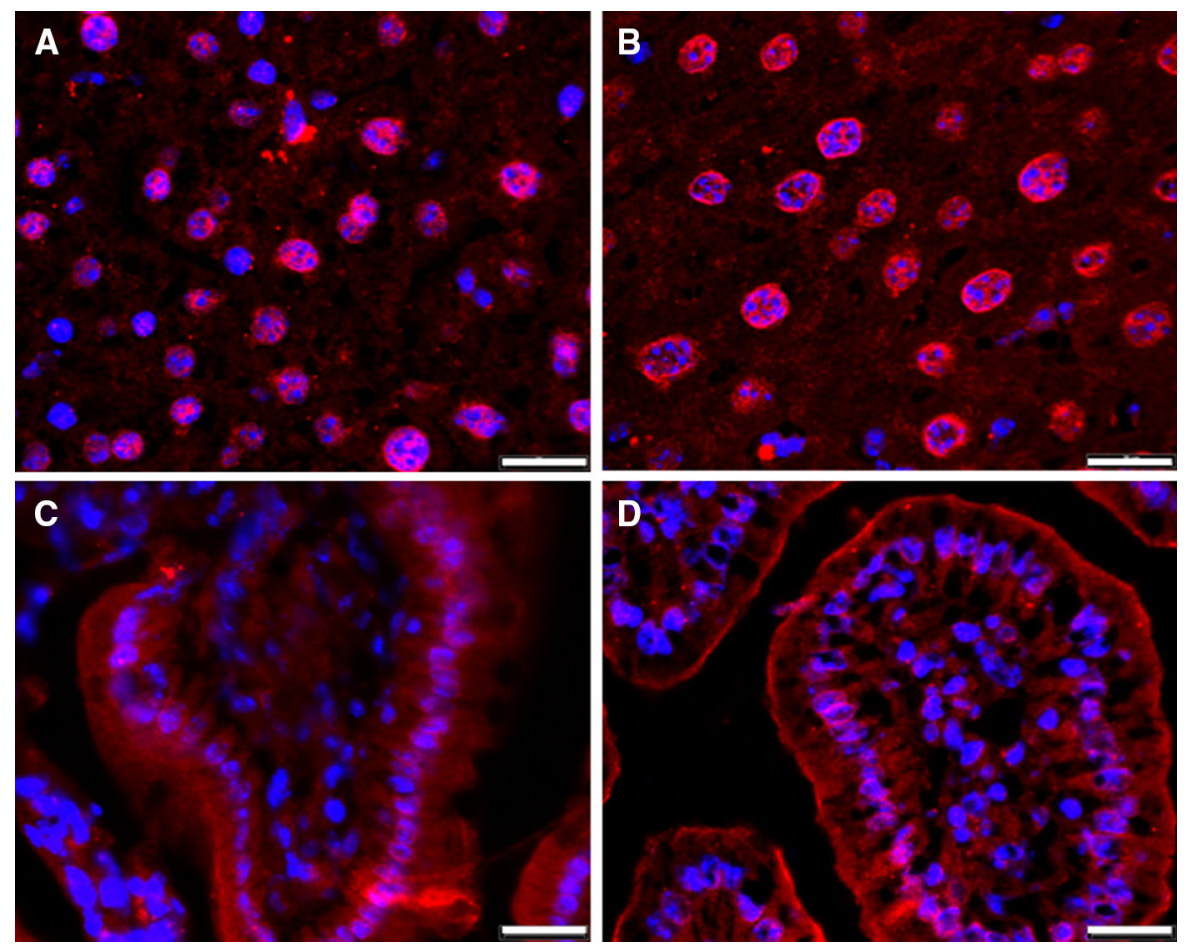

Fig. 3 Localization of metallothionein (MT) in liver and duodenum. a-d Immunofluorescence staining of liver (a, b) and duodenum (c, d) with anti-MT (red) in Atp7b $\mathrm{b}^{(-/-)}$mice

$(\mathbf{b}, \mathbf{d})$ and wildtype mice $(\mathbf{a}, \mathbf{c})$. Cell nuclei were visualized with Hoechst (blue). Scale bar $20 \mu \mathrm{m}$. (Color figure online)
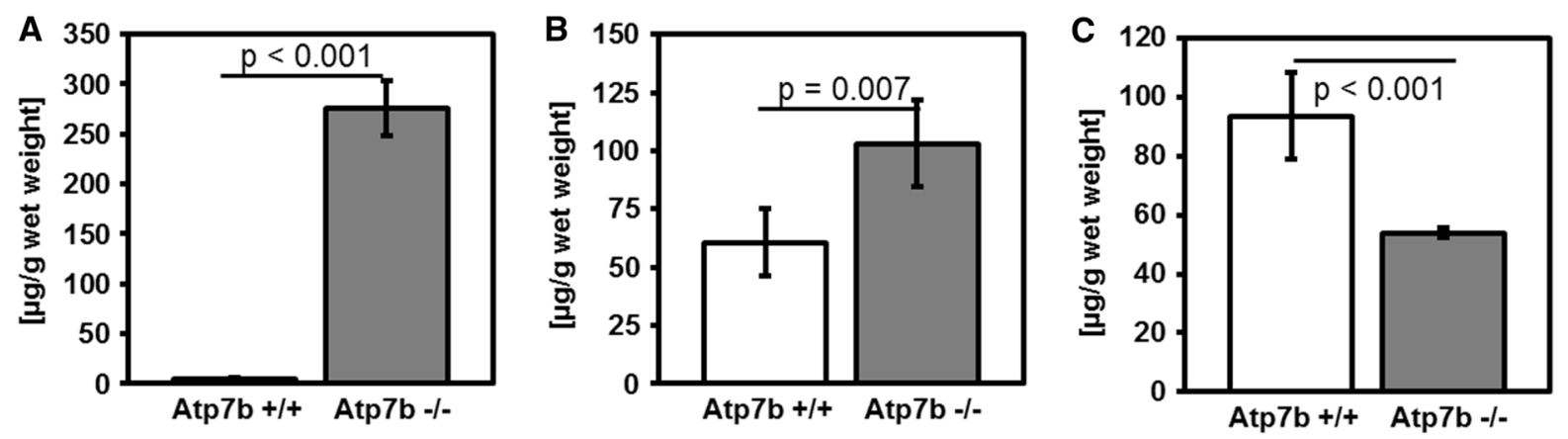

Fig. 4 Hepatic copper $(\mathrm{Cu})$, iron $(\mathrm{Fe})$ and zinc $(\mathrm{Zn})$ content of 13 -weeks-old $\operatorname{Atp} 7 \mathrm{~b}^{(-)}(\mathrm{n}=5)$ and wildtype mice $(\mathrm{n}=5)$ of the same age. a Hepatic $\mathrm{Cu}$ content of $\mathrm{Atp} \mathrm{b}^{(-/-)}$mice compared with wildtype mice. Hepatic $\mathrm{Cu}$ content $(\mu \mathrm{g} / \mathrm{g}$ wet weight) is significantly higher in Atp $7 \mathrm{~b}^{(-/-)}$mice compared with wildtype mice. b Hepatic Fe content of Atp $7 b^{(-1-)}$ mice

expression in association to Atp7b and measured the concentrations of copper, iron and zinc.

The results of our study showed significantly higher concentrations of metallothionein in the liver of Atp $7 \mathrm{~b}^{(-/-)}$mice compared to controls. These findings are consistent with the results of Huster et al. who compared with wildtype mice. Hepatic Fe content $(\mu \mathrm{g} / \mathrm{g}$ wet weight) is significantly higher in Atp $7 \mathrm{~b}^{(-/-)}$mice compared with wildtype mice. c Hepatic Zn content of Atp7 $\mathrm{b}^{(-/-)}$mice compared with wildtype mice. Hepatic $\mathrm{Zn}$ content $(\mu \mathrm{g} / \mathrm{g}$ wet weight) is significantly lower in Atp $7 b^{(-/-)}$mice compared with wildtype mice

reported a significant upregulation of MT1/2 in the liver of Atp $7 \mathrm{~b}^{(-/-)}$mice on protein and mRNA level (Huster et al. 2007) and in livers of adult toxic milk mice, a mutant animal, which also serves as model for Wilson's disease, Mercer et al. could also show a tenfold elevation in MT and MT1 mRNA levels 

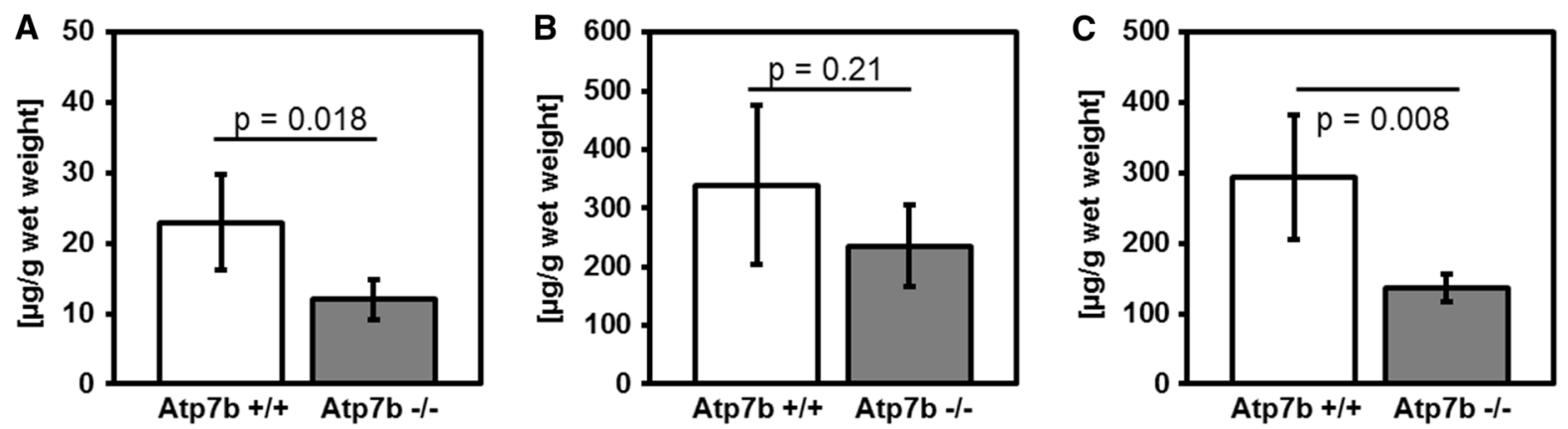

Fig. 5 Duodenal copper $(\mathrm{Cu})$, iron $(\mathrm{Fe})$ and zinc $(\mathrm{Zn})$ content of 13-weeks-old Atp7 $\mathrm{b}^{(-/-)}(\mathrm{n}=5)$ and wildtype mice $(\mathrm{n}=5)$ of the same age. a Duodenal $\mathrm{Cu}$ content of Atp $7 \mathrm{~b}^{(-1-)}$ mice compared with wildtype mice. Duodenal $\mathrm{Cu}$ content $(\mu \mathrm{g} / \mathrm{g}$ wet weight) is significantly lower in Atp $7 b^{(-/-)}$mice compared with wildtype mice. b Duodenal Fe content of Atp $7 \mathrm{~b}^{(-/-)}$mice

(Mercer et al. 1994). Nakazato et al. also reported elevated serum and urinary levels of MT1/2 in LongEvans Cinnamon (LEC) rats, another model for Wilson's disease, and elevated serum MT1/2 levels in patients with Wilson's disease (Nakazato et al. 2012, 2014).

Increased concentrations of metal ions in organs lead to an induction of metalloenzymes and metalloproteins. Therefore it seems to make sense, that the excessive copper accumulation in the liver of Atp $7 \mathrm{~b}^{(-/-)}$mice leads to an increased expression of MT. Liver-MT as well as serum-MT are described to be loaded with copper and are present as $\mathrm{Cu}-\mathrm{MT}$ in Wilson patients and LEC rats (Nakazato et al. 2014; Sakurai et al. 1992a, b). The increased protein expression of MT seems to be a physiologically answer of the organism to answer the excessive copper levels which occur in the liver and plasma during the progression of Wilson's disease at the stage of an acute hepatitis. With MTs binding free copper in the liver the toxic effect of this metal is reduced (Suzuki 1995). Beyond the copper-binding capacity of MT free copper starts increasing during the progression of Wilson's disease. Increased levels of free copper in the liver cause cellular damage as free copper is able to catalyze special reactions leading to an increased generation of aggressive hydroxyl radicals, which play an important role in inflammation and carcinogenesis (Halliwell et al. 1992; Koizumi et al. 1998).

The intestine also expresses MT, but little is known about the contribution of intestinal MT to normal copper homeostasis. Our results showed a significantly compared with wildtype mice. Duodenal Fe content $(\mu \mathrm{g} / \mathrm{g}$ wet weight) is lower in Atp $7 b^{(-/)}$mice compared with wildtype mice. c Duodenal Zn content of Atp $7 b^{(-1-)}$ mice compared with wildtype mice. Duodenal $\mathrm{Zn}$ content $(\mu \mathrm{g} / \mathrm{g}$ wet weight) is significantly lower in Atp $7 \mathrm{~b}^{(-/-)}$mice compared with wildtype mice

increased concentration of MT in the duodenum of Atp $7 \mathrm{~b}^{(-1-)}$ mice compared to controls. Similar to the liver-MT the underlying mechanisms in the duodenum might be due to the stimulation of metallothionein in the duodenum, which functions as endogenous chelator. In the cytosol of enterocytes MT binds newly absorbed copper and zinc, prevents their absorption from the gut into the circulation and consequently reduces the uptake of copper and zinc in the duodenum. Pierson et al. reported that ATP7b regulates vesicular storage of copper in the intestine of mice and could also show reduced copper storage pools in the intestine of Atp $7 \mathrm{~b}^{(-/-)}$mice (Pierson et al. 2018). On the other hand zinc is also an inductor of MT (Hamer 1986) and might affect $\mathrm{Cu}$ and $\mathrm{Fe}$ transport from the gut into the circulation through competitive transport mechanisms, but evidence for this mechanism is still weak. Furthermore a competitive binding pattern of $\mathrm{Zn}$ and $\mathrm{Cu}$ on MT could also explain the observed lower hepatic $\mathrm{Zn}$ concentrations in Atp $7 \mathrm{~b}^{(-1-)}$ mice. And especially zinc salts are being used frequently as therapeutic option for patients with Wilson's disease for decades. The intestinal MT induction seems to mediate the decreased copper absorption observed during zinc therapy for Wilson's disease (Medici et al. 2002; Santon et al. 2003).

In conclusion our study showed a significantly higher expression of metallothionein in the liver and duodenum of $A t p 7 b^{(-1-)}$ mice in comparison to wildtype mice and there is evidence that the elevated concentration of metallothionein seems to be a physiologically mechanism in Wilson's disease to 
compensate and regulate the excessive copper accumulation.

\section{Compliance with ethical standards}

Conflict of interest The authors declare that they have no conflict of interest.

Open Access This article is distributed under the terms of the Creative Commons Attribution 4.0 International License (http:// creativecommons.org/licenses/by/4.0/), which permits unrestricted use, distribution, and reproduction in any medium, provided you give appropriate credit to the original author(s) and the source, provide a link to the Creative Commons license, and indicate if changes were made.

\section{References}

Bremner I (1991) Nutritional and physiologic significance of metallothionein. Methods Enzymol 205:25-35

Buiakova OI, Xu J, Lutsenko S, Zeitlin S, Das K, Das S, Ross BM, Mekios C, Scheinberg IH, Gilliam TC (1999) Null mutation of the murine ATP7B (Wilson disease) gene results in intracellular copper accumulation and late-onset hepatic nodular transformation. Hum Mol Genet 8:1665-1671

Bull PC, Thomas GR, Rommens JM, Forbes JR, Cox DW (1993) The Wilson disease gene is a putative copper transporting P-type ATPase similar to the Menkes gene. Nat Genet 5:327-337

Coyle P, Philcox JC, Carey LC, Rofe AM (2002) Metallothionein: the multipurpose protein. Cellular and molecular life sciences: CMLS 59:627-647

Ferenci P, Caca K, Loudianos G, Mieli-Vergani G, Tanner S, Sternlieb I, Schilsky M, Cox D, Berr F (2003) Diagnosis and phenotypic classification of Wilson disease. Liver Int 23:139-142

Gehrke SG, Kulaksiz H, Herrmann T, Riedel HD, Bents K, Veltkamp C, Stremmel W (2003) Expression of hepcidin in hereditary hemochromatosis: evidence for a regulation in response to the serum transferrin saturation and to nontransferrin-bound iron. Blood 102:371-376

Halliwell B, Gutteridge JM, Cross CE (1992) Free radicals, antioxidants, and human disease: where are we now? J Lab Clin Med 119:598-620

Hamer DH (1986) Metallothionein. Annu Rev Biochem 55:913-951

Herrmann T, Muckenthaler M, van der Hoeven F, Brennan K, Gehrke SG, Hubert N, Sergi C, Grone HJ, Kaiser I, Gosch I, Volkmann M, Riedel HD, Hentze MW, Stewart AF, Stremmel W (2004) Iron overload in adult Hfe-deficient mice independent of changes in the steady-state expression of the duodenal iron transporters DMT1 and Ireg1/ferroportin. J Mol Med 82:39-48

Huster D, Finegold MJ, Morgan CT, Burkhead JL, Nixon R, Vanderwerf SM, Gilliam CT, Lutsenko S (2006) Consequences of copper accumulation in the livers of the
Atp $7 b^{-1-}$ (Wilson disease gene) knockout mice. Am J Pathol 168:423-434

Huster D, Purnat TD, Burkhead JL, Ralle M, Fiehn O, Stuckert F, Olson NE, Teupser D, Lutsenko S (2007) High copper selectively alters lipid metabolism and cell cycle machinery in the mouse model of Wilson disease. J Biol Chem 282:8343-8355

Koizumi M, Fujii J, Suzuki K, Inoue T, Gutteridge JM, Taniguchi N (1998) A marked increase in free copper levels in the plasma and liver of LEC rats: an animal model for Wilson disease and liver cancer. Free Radic Res 28:441-450

Lutsenko S, Barnes NL, Bartee MY, Dmitriev OY (2007) Function and regulation of human copper-transporting ATPases. Physiol Rev 87:1011-1046

Medici V, Santon A, Sturniolo GC, D'Inca R, Giannetto S, Albergoni V, Irato P (2002) Metallothionein and antioxidant enzymes in Long-Evans Cinnamon rats treated with zinc. Arch Toxicol 76:509-516

Mercer JF, Paynter JA, Grimes A (1994) The toxic milk mouse does have elevated hepatic metallothionein mRNA. Biochem J 304(Pt 1):317-318

Muckenthaler M, Roy CN, Custodio AO, Minana B, deGraaf J, Montross LK, Andrews NC, Hentze MW (2003) Regulatory defects in liver and intestine implicate abnormal hepcidin and Cybrd1 expression in mouse hemochromatosis. Nat Genet 34:102-107

Mulder TP, Janssens AR, Verspaget HW, van Hattum J, Lamers CB (1992) Metallothionein concentration in the liver of patients with Wilson's disease, primary biliary cirrhosis, and liver metastasis of colorectal cancer. J Hepatol 16:346-350

Nakazato K, Nakajima K, Nakano T, Kodaira T, Nakayama K, Satoh M, Nagamine T (2012) Metallothionein (MT) 1/2 expression in MT 1/2 and MT 3 knock-out mice and LongEvans Cinnamon (LEC) rats. J Toxicol Sci 37:169-175

Nakazato K, Tomioka S, Nakajima K, Saito H, Kato M, Kodaira T, Yatsuzuka S, Shimomura Y, Hiroki T, Motoyama K, Kodama H, Nagamine T (2014) Determination of the serum metallothionein (MT) $1 / 2$ concentration in patients with Wilson's disease and Menkes disease. J Trace Elem Med Biol 28:441-447

Nartey NO, Frei JV, Cherian MG (1987) Hepatic copper and metallothionein distribution in Wilson's disease (hepatolenticular degeneration). Lab Investig $\mathbf{J}$ Tech Methods Pathol 57:397-401

Nicholson JR, Savory MG, Savory J, Wills MR (1989) Microquantity tissue digestion for metal measurements by use of a microwave acid-digestion bomb. Clin Chem 35:488-490

Nishimura H, Nishimura N, Tohyama C (1989) Immunohistochemical localization of metallothionein in developing rat tissues. J Histochem Cytochem 37:715-722

Okayasu T, Tochimaru H, Hyuga T, Takahashi T, Takekoshi Y, Li Y, Togashi Y, Takeichi N, Kasai N, Arashima S (1992) Inherited copper toxicity in Long-Evans cinnamon rats exhibiting spontaneous hepatitis: a model of Wilson's disease. Pediatr Res 31:253-257

Pierson H, Muchenditsi A, Kim BE, Ralle M, Zachos N, Huster D, Lutsenko S (2018) The function of ATPase copper transporter ATP7B in intestine. Gastroenterology 154(168-80):e5 
Sakurai H, Fukudome A, Tawa R, Kito M, Takeshima S, Kimura M, Otaki N, Nakajima K, Hagino T, Kawano K et al (1992a) Unusual accumulation of copper related to induction of metallothionein in the liver of LEC rats. Biochem Biophys Res Commun 184:1393-1397

Sakurai H, Kamada H, Fukudome A, Kito M, Takeshima S, Kimura M, Otaki N, Nakajima K, Kawano K, Hagino T (1992b) Copper-metallothionein induction in the liver of LEC rats. Biochem Biophys Res Commun 185:548-552

Santon A, Irato P, Medici V, D’Inca R, Albergoni V, Sturniolo GC (2003) Effect and possible role of Zn treatment in LEC rats, an animal model of Wilson's disease. Biochem Biophys Acta 1637:91-97

Sugawara N, Sugawara C, Sato M, Katakura M, Takahashi H, Mori M (1991) Copper metabolism in LEC rats aged 30 and 80 days old: induction of $\mathrm{Cu}$-metallothionein and status of zinc and iron. Res Commun Chem Pathol Pharmacol 72:353-362

Suzuki KT (1995) Disordered copper metabolism in LEC rats, an animal model of Wilson disease: roles of metallothionein. Res Commun Mol Pathol Pharmacol 89:221-240
Tanzi RE, Petrukhin K, Chernov I, Pellequer JL, Wasco W, Ross B, Romano DM, Parano E, Pavone L, Brzustowicz LM et al (1993) The Wilson disease gene is a copper transporting ATPase with homology to the Menkes disease gene. Nat Genet 5:344-350

Theophilos MB, Cox DW, Mercer JF (1996) The toxic milk mouse is a murine model of Wilson disease. Hum Mol Genet 5:1619-1624

Tohyama C, Suzuki JS, Hemelraad J, Nishimura N, Nishimura H (1993) Induction of metallothionein and its localization in the nucleus of rat hepatocytes after partial hepatectomy. Hepatology 18:1193-1201

Widdowson EM, Spray CM (1951) Chemical development in utero. Arch Dis Child 26:205-214

Widdowson EM, Chan H, Harrison GE, Milner RD (1972) Accumulation of $\mathrm{Cu}, \mathrm{Zn}, \mathrm{Mn}, \mathrm{Cr}$ and $\mathrm{Co}$ in the human liver before birth. Biol Neonate 20:360-367

Wu J, Forbes JR, Chen HS, Cox DW (1994) The LEC rat has a deletion in the copper transporting ATPase gene homologous to the Wilson disease gene. Nat Genet 7:541-545 